\title{
The taboo of violence and the need for parental authority
}

\section{Opinion}

Violence is inherent to human condition. It is born of the frustration of our omnipotence, our vital energy. This violence that we want to restrain and ignore has a price to be paid. The inevitable circulation of this violence means that if the parents do not take responsibility for it, it comes to the child who does not have the psychic means to contain it, in the form of rage first and then of aggression against himself. Self-injury is a very visible form, but there are also risky behaviors and the ideomotor slowing of depression.

\section{The taboo of violence}

Violence is natural and an integral part of our human condition and it is a good thing. This violence is intrinsically linked to our life drive, to our vital energy, our libido. This violence we observe as something normal in animal behavior for its survival, to defend itself, to feed or even to reproduce. This violence we have been taught to hate and ignore in ourselves to be better socialized, forgetting that socialization is a domestication that aims to break this vital drive of the individual, to deny his omnipotence. There is a balance to be found here, and above all an acceptance which requires first to acknowledge it.

The omnipotence of the newborn exists in the fact that for him, he is not born into the world but it is the world that is born for him. There is no differentiation at the origin. He exists only through all his feelings and the world among them. When the need arises, if his mother is slow to answer, the child hallucinates the answer to his feeling of lack. For example, he will suck his thumb to hallucinate the breast or bottle that comes to him to satisfy his feelings of discomfort related to hunger. The most important thing for this little "social" being is especially the relationship. From birth, the child is taken into the relationship, in particular to his mother. The relationship is vital to the survival of the newborn that is made to overcome its absence by hallucination. From the gap between hallucination and reality, the baby gradually becomes aware of the existence of his mother outside of him. It is the lack and frustration of his omnipotence, tempered and acceptable, that will allow the child to do the psychic work that will gradually lead him to differentiate himself from his mother, to differentiate his ego and the other. Omnipotence also persists and safeguards the continuity of its being.

Nature is thus made that the hormonal game usually leads the mother to a "transient madness", to a "primary maternal preoccupation" that makes her obsessed exclusively by her newborn and puts herself at his disposal. There is a subtle tuning where the mother puts herself at the level of her child, for example by amplifying the stimuli (voice, gesture, etc.) to share with him the pleasure experienced as a satisfactory extension of his omnipotence, "good", but inevitably always a little "bad", a gradient of feelings of discomfort that represents so many small touches of frustration to his omnipotence. This frustration brings him to the world by imposing on him something else by nature that the pleasure inherent to his omnipotence, the different that allows him to differentiate himself at the same time as his mother. Individuation is essentially a more or less
Volume 9 Issue 4 - 2018

\author{
Veronique Elefant-Yanni \\ Clinical Psychologist \& Psychotherapist, University of Geneva, \\ Switzerland
}

\begin{abstract}
Correspondence: Veronique Elefant-Yanni, Clinical Psychologist \& Psychotherapist, University of Geneva, Switzerland, Tel (65) 87223369 ,
\end{abstract}

Email veronique.elefant-yanni@msn.com

Received: July 13, 2018 | Published: July 30, 2018

successful frustration of omnipotence.

Now there are times when the hallucination is no longer enough, when the discomfort is so unbearable that it is exteriorized by cries and anger. When you hurt, you shout the same way, but you can have an action on the world to channel your omnipotence and remedy that pain in general. The baby cannot have direct action on the world to calm his discomfort; the frustration of his omnipotence is experienced as an attack on his ability to survive. Without the other, the child could not survive. When we look at an angry baby, we are impressed by the violence that he releases compared to his small person. It does not matter because a baby does not have the physical strength that could inflict damage around him, but imagine the same degree of rage in a teenager who has physical strength and no ability to bear the frustration, no control of oneself; one's impulses ... and you have a juvenile delinquent image.

When the baby has already started to form a maternal object outside of him, he has the feeling that his discomfort comes from the absence of his mother that he could not "create", and so somehow that he destroyed. The anger of frustration turns into guilt for destroying the beloved mother. This negative image of the maternal object is a loss of the libido that the child has invested in it, a loss of a part of his vital energy, an attack on his survival. The violence born from the frustration of the omnipotence then becomes punitive and is turned against the self in a deflation, a depression. If this situation is temporary and the satisfactory answer arrives to put an end to the malaise, if the frustration is given by homeopathic dose, the child comes out with a consolidated omnipotence but also with a better control of his frustrations because he did experience that they will not destroy him.

In cases where the situation lasts too long, an "infantile depression" is structured with two possible outcomes depending on the duration. In the best case, the child grows up with "belly rage", rebelling against any form of authority, and without graduation to his tantrums system on-off. Any frustration sounds like an attack on his survival. In the other case, the child has gone to the self-punitive stage. He sees himself as bad, bad because he feels this violence in him and is afraid of him, afraid to destroy those he loves. He remains frozen in 
the slowing of depression, stopping himself from living in an attempt to protect those he loves. In both cases, children are afraid of their own violence, which they see through the prism of omnipotence as destructive and dangerous for their parents.

In this context, to show authority is to take responsibility for the violence and to discharge the child by offering him a framework that relieves him of his uneasiness, his physical feelings of unease.

\section{The need for parental authority}

It is precisely here that parental authority is necessary. You have to understand that there is a circulation of violence, if you refuse the responsibility that is yours in its sharing and its balance, too much violence will come out somewhere in the tantrums of your children that reflect the malaise where they are. Parental authority demands violence, if only in coercion. It is impossible to escape, and one must understand its necessity to assume it without guilt. Parental authority relieves the child of the responsibility of violence, and therefore of the guilt that is his in the fantasy of his omnipotent and destructive violence. This frees him from his guilt. The second effect is that he survives the frustration of his restrained anger. He gradually internalizes parental control and controls his frustrations and impulses. The framework that is thus defined for him helps him to structure himself.

Parents may have different reasons for refusing their responsibility for parental authority. Some may want to take a stand against the model of their own parents because they have abused their parental authority and have been excessively violent in their corrections. Sometimes these memories of children are also exaggerated, and they forget that this parental authority that they reject a posteriori allowed them to be the adults they are today. Sometimes parents are afraid of losing the love of their children if they are harsh. The bond between a child and his parents is so strong that even abused children (and I'm not talking about authority here, but abuse) love their parents. It is not a question of beating them, but of exercising reasonable violence to contain the child's violence and to release him from his responsibility and the guilt that accompanies it.

A parent cannot be his child's friend; he has a responsibility to assume that places him in a de facto unequal position. Finally, the last scenario concerns parents who feel that something is not working but choose to ignore it by ideology. The "positive parenting" that preaches the abandonment of parental authority and coercion is nonsense that does not respect the nature of the child. The young human is born immature with a natural need for guidance and education. Parental authority meets this need. You can see it in other mammals in the wild, and human being is a mammal among others. The ideal of a mature human being is a goal towards which to tend, if you forget the steps to climb or do not want to see them, you stay down.

Again, it is not a question of beating your children, but of correcting them. If you feel angry, or "go off the rails", do not run wild on your children with the excuse of exercising parental authority. This is not to condone parental abuse either. If, as a parent, you are afraid of your own violence, count to three aloud. It will give you time to calm down and recover before you exercise your authority with reason. With time, the correction will not be necessary, counting will be enough. The goal is to allow the child to internalize this parental control. When the child grows up, an explanation can take over as long as acceptance of frustration is gained.

When the process goes on without too much trouble, around the age of 7 , the child completes his individuation. He is no longer rationally the creator of the world and consequently his parents become truly mortal. Nightmares express the terror of their disappearance and with them the important libidinal investment he has placed in them and which would be a loss of vital energy of such importance that the survival of the child's ego seems compromised. In my practice, I was able to note that if we explain to children that we are all energy and that the energy never disappears but changes, even if we do not know how and we cannot have any more contact with those we love, this simple explanation satisfies them enough for the nightmares to cease. The conviction that energy is not lost, even for the self, but just transformed, no longer threatens libidinal investment and the ego.

\section{Acknowledgments}

None.

\section{Conflict of interest}

The author declares that there is no conflict of interest. 